the act was passed. This act required an examination in physics and surgery, approved of, and admitted by any two judges of the Supreme Court, taking to their assistance for the examination such proper persons as they should deem fit, and the Court gave a certificate of examination, without which any one (except those licensed by the crown or physicians from other Colonies) practicing in the Colony was liable to a fine. It also legalized physicians' fees.

In 1774 , an effort was made by the Society to procure a charter, which was delayed by the Revolution, but granted by the State in 1790 . There was an intermission of the regular meetings of the Society from 1775 to 1781 , because the local situation of the war rendered it dangerous for members to travel through the Colony, and because, also, many of the members took an active part in the Revolution. As soon, however, as civil government was restored, the Society convened, Nov. 6, 1781, at Princeton. The complete records of the Society have been preserved since its organization in 1766 , and the Medical Society of New Jersey claims to be the oldest State Medical Society in the United States, and among the first to secure an act from its Colonial Assembly to legalize and regulate the practice of medicine. The first State law regulating medical practice in New Jersey was passed in 1783 . Very respectfully,

E. L. B. Godfrey, M.D.

\section{Cheap Colleges.}

Spokane, Wash., Sept. 26, 1893.

To the Editor:-My article published in The Journal of the $23 \mathrm{~d}$ inst., was not intended as an advertisement of my qualifications, which I am proud to say are as good as can be obtained in the United States, but to call your attention to the false position you are putting our really good colleges by constantly advertising inferior ones. Until within the last two years the German universities would recognize tickets for time spent in some of our best schools, but now they refuse to so recognize time spent in any of them. They say they can not distinguish between the good and the poor schools, we have so many of them. And it seems natural that they should not when The Journal will not.

I hope to see the day when a "Yankee" M.D. degree will rank with any obtained in Europe and it seems to me that one of the first steps toward attaining that end will be for The Joursis to refuse to recognize in any way, any but our very best colleges and universities. We have in the United States, about one hundred and forty colleges and universities granting the degree of M.D.; probably forty of those have such facilities for teaching medicine as ought to entitle them to recognition anywhere. The others are run for revenue only, or to advertise the faculty connected with them or both, and they should be ignored by the AMERICAs Medical Assoclation and its Journal, or if noticed at all only to call attention to the fact that they are a disgrace to the profession, and that their course does not meet with the approval of the better element of the profession here.

$$
\text { Yours, D.C. NewMas. }
$$

As this letter related to the business management of THE Joursal, and involved a censorship of the colleges, it was handed to one of the Trustees to look over; that officer did not return it immediately, and the matter rested in his tiands, and was not returned until the receipt of the following letter when its return was called for by the editor.

The elevation of the city of Spokane above the sea level makes ebullition easy, and our friend seemed to grow excited. He writes:

Spokane, Wash., Oct. 25, 1893.

Dear Sir:-In my article published in our Jounsal of the $23 d$ of September, you chose to slur me by a head line that newspaper men would count as entirely uncalled for and poor taste. I replied at once, but you continue your unprofessional tactics by refusing to publish the reply. You attempt to deceive me by not noticing it among Letters Received, but as the letter has not returned to me, of course you received it. I readily see that to publish such letters as mine would be bad politics, as many of the professors of these second and third class colleges and diploma mills have a voice in the Americis MeDichl Association, and are often elected to vice-presidencies; and as you are evidently in sympathy with these people and running THE JOURNAL for Dr. Hamilton, nothing else can be expected of you. So I inclose stamp for return of the manuscript.

Yours very truly,

D. C. NewMaN.

\section{American Women are Physically Degenerating.}

Washivgton, D. C., October, 1893.

To the Editor:-In 'The Jov RNA , of October 21, Dr. Edmund Andrews of Chicago, takes up the article of Dr. Cyrus Edson on deterioration of American women, published in the October number of the North American Review, and gives us the the more cheerful if not the exact status of American motherhood.

With Dr. Andrews the wish is evidently father to the thought; for if we examine the facts as they are presented to us in everyday life, we find there is almost a unanimity of opinion among physicians, nurses and mothers of grown children, that women of the last two decades of years seem to suffer more, become sooner physically exhausted and are slower rallying from childbirth than their mothers before them.

Taking haphazard the names of some of those married within the last ten years, of my acquaintance, one can not but see a picture of suffering and invalidism, which leaves but little doubt that the present modus vivendi of lovely women is radically wrong. Is the wrong wrought "in the schools, where by ambition and by rewards for success and disgrace for failure, growing girls are goaded to a disastrous amount of mental strain and over brain work;" or must we go farther back, to the mothers of our present wives and blossoming maidens, when frequent and multitudinous child bearing was more common, and the style of tight lacing and high heels was in vogue; mothers then bringing into the world offspring whose uterine life was spent in a sub-involuted tissue and whose narrow confines were restricted and hampered.

Of the names of forty-eight mothers, some primiparæ, others multiparæ, all married within ten years, I find there are but twenty who may be said to enjoy as good health as before they were married. Of the remaining twenty-eight, seven died, incident to or following childbirth, five are bedridden, and the remaining sixteen have never regained their former good looks and health.

Our American women are pretty; as proportionately and beautifully formed as ever. They have the courage and will to carry them through long suffering; but too often the reserve physical force soon gives out even with little exertion, and leaves us to terminate a protracted labor as best we can. James D. Morgan, M.D.

\section{Ohio Epileptic Asylum.}

The following communication has been received, addressed "To the State and county officers and the public:"

I am advised by the Board of Trustees of the Ohio Hospital for Epileptics, that they are about ready to open for the admission of 250 male patients, but are not yet provided with the proper information to enable them to enumerate and classify the applicants for admission.

The probate court of each county has proper blank forms for application, and it is earnestly desired that all who seek the care of this institution shall call upon the probate judge and fill out these blanks and forward to Dr. H. C. Rutter, Manager, Gallipolis, O., at once. Very truly,

W. MICKINLEY, JR., Governor.

\section{Is It a Swindle?}

Toledo, OHIo, Oet. 28, 1893.

To the Editor:-Some months ago a lady representing herself as the granddaughter of Dr. McDowell, canvassed this and neighboring cities, taking orders for the "Biography of 